\title{
CONTRIBUTIONS OF NURSES IN BASIC RESEARCH: DRESSING FIXATION MODEL FOR EXCISIONAL CUTANEOUS WOUNDS OF MICE
}

\author{
Gilmara Lopes Amorim¹ (D), Mariana Raquel Soares Guillen (D), Puebla Cassini Vieira² (D), \\ Lucíola da Silva Barcelos ${ }^{3}$ (1), Eline Lima Borges ${ }^{1, *}$ (1)
}

\begin{abstract}
Objective: validate method of fixation of dressings on excisional cutaneous wounds of mice. Method: preclinical study. Sample made up of animals of the C57BL/6 strain, which had two excision wounds made in the dorsal region. Different methods and products, widely accepted in clinical practice, for fixing dressings in the animal model were evaluated. The evaluated outcomes were the length of stay of the dressing and the occurrence of adverse events. Results: crepe bandage, microporous tape and self-adhesive bandage had a shorter residence time when compared to polyurethane film. This, in turn, varied the time when comparing different marks $(E, F, G$ and $H)$ and number of turns around the animal's body. With 1 lap, the time varied from <24 to 36 hours. With 2 laps, the marks E and G remained 48 and 96 hours, respectively, and F and $\mathrm{H}$ time $<24$ hours. G-brand film, cut to size $3 \mathrm{~cm} \times 15 \mathrm{~cm}$, giving the mouse body 2 turns, kept the dressing for 96 hours. The skin remained intact, with no adverse event. Conclusion: a dressing fixation model for wounds in mice was created with a product available in Brazil and compatible with the animal's body structure.
\end{abstract}

DESCRIPTORS: Healing. Bandages. Basic research. Stomatherapy.

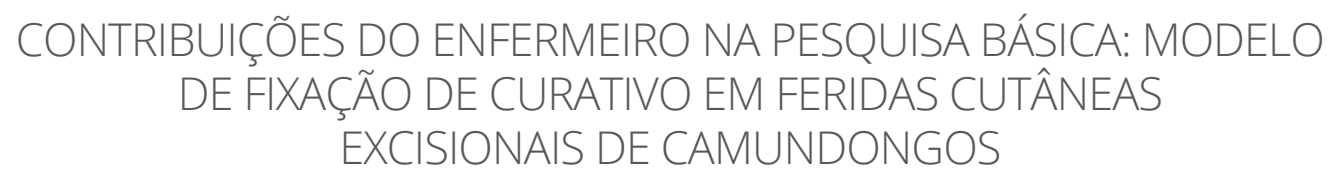

\section{RESUMO}

Objetivo: validar método de fixação de curativos em feridas cutâneas excisionais de camundongos. Método: estudo préclínico. Amostra composta por animais da linhagem C57BL/6, que tiveram duas feridas excisionais confeccionadas na região dorsal. Foram avaliados diferentes métodos e produtos, amplamente aceitos na prática clínica, para fixação de curativos no modelo animal. Os desfechos avaliados foram tempo de permanência do curativo e ocorrência de eventos adversos. Resultados: atadura de crepom, fita microporosa e bandagem autoaderente apresentaram menor tempo de permanência quando comparadas ao filme de poliuretano. Esse, por sua vez, variou o tempo quando comparadas diferentes marcas (E, F, G e H) e número de voltas ao redor do corpo do animal. Com 1 volta, o tempo variou de $<24$ a 36 horas. Com 2 voltas, as marcas E e G permaneceram 48 e 96 horas, respectivamente, e F e $\mathrm{H}$ tempo < 24 horas. Filme da marca G, cortado no tamanho $3 \mathrm{~cm} \times 15 \mathrm{~cm}$, dando 2 voltas no corpo do camundongo, manteve o curativo por 96 horas. A pele permaneceu íntegra, sem evento adverso. Conclusão: foi criado modelo de fixação de curativos para feridas em camundongos com produto disponível no Brasil e compatível com a estrutura copórea do animal.

DESCRITORES: Cicatrização. Bandagens. Pesquisa básica. Estomaterapia.

1. Universidade Federal de Minas Gerais - Escola de Enfermagem - Departamento Enfermagem Básica - Belo Horizonte (MG), Brazil.

2. Universidade do Estado de Minas Gerais - Departamento de Ciências Biológicas - Belo Horizonte (MG), Brazil.

3. Universidade Federal de Minas Gerais - Instituto de Ciências Biológicas - Departamento de Fisiologia e Biofísica - Belo Horizonte (MG), Brazil.

*Correspondence author: elineufmg@gmail.com

Section Editor: Manuela de Mendonça F Coelho

Received: Abr. 2021, 01 | Accepted: Abr. 2021, 28

How to cite: Amorim GL; Guillen MRS; Vieira PC; Barcelos LS; Borges EL. Contributions of nurses in basic research: dressing fixation model for excisional cutaneous wounds of mice. ESTIMA, Braz. J. Enterostomal Ther., 2021, 19: e1221. https://doi. org/10.30886/estima.v19.1038_IN 


\title{
CONTRIBUCIONES DEL ENFERMERO EN LA INVESTIGACIÓN BÁSICA: MODELO DE FIJACIÓN DE APÓSITO EN HERIDAS CUTÁNEAS EXCISIONALES DE RATONES
}

\begin{abstract}
RESUMEN
Objetivo: validar método de fijación de apósitos en heridas cutáneas excisionales de ratones. Método: estudio preclínico. Muestra compuesta por animales del linaje C57BL/6 que tuvieron dos heridas excisionales confeccionadas en la región dorsal. Se evaluaron distintos métodos y productos, ampliamente aceptados en la práctica clínica, para fijación de apósitos en el modelo animal. Los resultados evaluados fueron tiempo de permanencia del apósito y ocurrencia de eventos adversos. Resultados: La venda de crepé, la cinta microporosa y el vendaje autoadherente presentaron menor tiempo de permanencia cuando comparados con la película de poliuretano. Esta, a su vez, varió en el tiempo cuando comparadas distintas marcas ( $E, F, G$ y H) y número de vueltas alrededor del cuerpo del animal. Con una vuelta completa, el tiempo varió de menos de 24 a 36 horas. Con dos vueltas, las marcas E y G permanecieron 48 y 96 horas, respectivamente, y F y H, tiempo igual e inferior a 24 horas. La piel permaneció íntegra, sin evento adverso. Conclusión: se creó un modelo de fijación de apósitos en ratones con un producto disponible en Brasil y compatible con la estructura del cuerpo del animal.
\end{abstract}

DESCRIPTORES: Cicatrización de heridas. Vendages. Investigación básica. Estomaterapia.

\section{INTRODUCTION}

Basic research can contribute to solving problems inherent to nursing care ${ }^{1}$ when the research results allow its translation into clinical practice ${ }^{2}$. The development of experimental model research by nurses becomes relevant, as it is possible to materialize reality and support the effect of nursing interventions. It is noteworthy that the animal model allows the evaluation of biological phenomena, which can be compared to humans ${ }^{3}$, with an emphasis on translational research.

Animal experimentation allows the understanding of knowledge gaps related to physiological and pathological processes, which can impact clinical nursing practice. There is variability in experimental studies that address the healing of skin wounds, but, contradictorily, these studies are conducted by other professional categories ${ }^{4,5}$. Such an issue may limit the implementation of nursing interventions in the treatment of wounds in the context of in vivo research.

In nursing, there is still a debate about the relevance of the use of animals in research on themes in this area of knowledge ${ }^{3}$. However, some studies started to be produced in the area, especially those aiming at the integration of basic science to the contents of tissue repair of wounds ${ }^{6,7}$. It is believed that the use of available technologies for the treatment of skin wounds can be improved by Nursing through the development of experimental and clinical research ${ }^{8}$. In this way, the effects of these products on the different stages of the skin wound healing process will be explained. In this context, doubts persist about the adequate fixation of the dressing to the animal skin.

The term dressing fixation, in this study, represents the act of applying a product to maintain primary coverage over the wound. It is understood that the fixation of a dressing must be able to guarantee the maintenance of the cover over the wound bed for a certain period of time, preserving and protecting the wound against possible trauma. Therefore, in order to carry out studies on the treatment of wounds in animals, especially mice whose nature is restlessness and the ability to remove everything applied to their back, the first step is to establish a dressing fixation model consistent with clinical nursing practice. Thus, the aim of this study is to validate a method of dressing fixation on excisional skin wounds of mice. 


\section{METHODS}

This is a pre-clinical trial with male, isogenic mice, lineage C57BL/6, aged between 7 and 8 weeks and body weight $\geq 17$ grams, to evaluate the outcomes, duration of dressing and adverse events.

The products used to fix the dressing were: crepe bandage fixed with adhesive tape (technique A) and sutured with cotton thread (technique B); self-adhesive bandage fixed under pressure, according to the manufacturer's recommendation (technique $\mathrm{A}$ ) and sutured with cotton thread (technique $\mathrm{B}$ ); microporous tape of the brand $3 \mathrm{M}^{\circledR}$ (C) and $\mathrm{Cremer}^{\circledR}(\mathrm{D})$; polyurethane film from the Systagenix ${ }^{\circledR}(\mathrm{E})$, Smith $\& \mathrm{Nephew}^{\circledR}(\mathrm{F}), 3 \mathrm{M}^{\circledR}(\mathrm{G})$ and $\mathrm{Curatec}^{\circledR}$ (H) brands.

The different types of fixation tested were repeated at least five times until they were considered inappropriate or appropriate. Next, two animals were used to test the crepe bandage, two for microporous tape, two for self-adhesive bandages and four animals for polyurethane film. The animals were submitted to anesthesia at each dressing change.

Crepe bandage, microporous tape, self-adhesive bandage and polyurethane film were cut into strips approximately $3 \mathrm{~cm}$ long (vertical position), in order to involve the entire dorsal and abdominal region of the mouse. The width (horizontal position) was standardized at $15 \mathrm{~cm}$ for all tested products, in order to allow two turns of the product around the animal's body. For the polyurethane film, tapes with a width of $8 \mathrm{~cm}$ were also used in the test, with a single turn of the film around the body of the mouse.

The study also evaluated the size of the cover to be applied to the excisional wound made with a $5 \mathrm{~mm}$ surgical punch. The evaluation included the application of a $1 \mathrm{~cm}^{2}$ plate dressing (one for each wound) and in a single rectangular shape, with the following dimensions: $1 \mathrm{~cm}$ long by $2 \mathrm{~cm}$ wide, to cover the entire area of the 2 wounds and ensure a small margin of overlapping of the skin around them.

Data collection took place in the first half of 2019. The study involved a sample of ten animals, which underwent five days of setting and adaptation before the excisional wound was applied and the dressing was applied. The animals were anesthetized with xylazine $2 \%$ at a dose of $10 \mathrm{mg} / \mathrm{kg}$ and ketamine $10 \%$ at a dose of $100 \mathrm{mg} / \mathrm{kg}$ (manufacturer Syntec), prepared in sterile $0.9 \%$ saline and administered intraperitoneally. Subsequently, these animals were submitted to trichotomy and asepsis of the dorsal region. The trichotomy was performed with a Wall ${ }^{\circledR}$ mini-trichotomizer, a portable model. Skin asepsis was performed with $70 \%$ alcoholic solution.

In each animal, two excision cutaneous wounds were performed in the middle region of the dorsum with the aid of a $5 \mathrm{~mm}$ diameter dermatological surgical punch. All skin tissue was removed, including epidermis, dermis, hypodermis and fleshy panicle. The wounds were made with a minimum distance of approximately $0.5 \mathrm{~cm}$ and a maximum of $1.0 \mathrm{~cm}$ between them? .

Then, coverage was applied over the wound and the dressing to be evaluated was fixed. The application followed the dressing fixation model ${ }^{10}$. The fixation was applied around the body of the mouse, in order to make one or two complete turns around the animal.

The integrity and maintenance of the fixation employed were evaluated every two hours for the first six hours after the end of the anesthetic effect, and every three hours for the subsequent six hours. After 12 hours from the beginning of the experiment, the evaluations were carried out every 6 hours until the dressing was partially or completely released. At the end of the experiment, the region around the wound was inspected to assess the integrity of the skin and identify adverse events.

During the study, the animals were kept in an exclusive room to house these animals, under controlled conditions of temperature $\left(24^{\circ} \mathrm{C}\right)$, light (12 hours light/dark cycle), in individual cages (polypropylene box with an approximate size of $25 \mathrm{~cm}^{3}$ ), with a distance of $5 \mathrm{~cm}$ (horizontal) and $60 \mathrm{~cm}$ (vertical) between them. The animals had free access to food and water, and the cages were cleaned twice a week to prevent the accumulation of ammonia in the environment.

At the end of the experiments, all animals were euthanized with overdose of anesthetic $2 \%$ xylazine at a dose of $30 \mathrm{mg} / \mathrm{kg}$ and ketamine $10 \%$ at a dose of $300 \mathrm{mg} / \mathrm{kg}$, both prepared in sterile $0.9 \%$ saline, administered intraperitoneally, followed by cervical dislocation, according to the Brazilian guide of good practices for euthanasia of animals, Resolution 
$n^{\circ} 714$, of the Conselho Federal de Medicina Veterinária and Normative Resolution No. 37 of the Conselho Nacional de Controle de Experimentação Animal (CONCEA).

The study was approved by the Ethics Committee on the Use of Animals of the Universidade Federal de Minas Gerais, under Protocol number 393/2015 and respected the ethical principles according to the current legislation for animal experimentation.

\section{RESULTS}

The dressing fixation time varied from 1 to 96 hours, according to the type and brand of the product (Table 1).

Table 1. Dressing fixation on the animal model with several products. Belo Horizonte (MG) - 2019.

\begin{tabular}{lc}
\hline Product used for fixation & $\begin{array}{c}\text { Permanence of the dressing } \\
\text { (hours after the end of the anesthetic effect) }\end{array}$ \\
\hline Crepe bandage & 1 hour 30 minutes \\
\hline$\cdot$ technique A - fixed with adhesive tape & 1 hour 30 minutes \\
\hline$\cdot$ technique B - fixed with suture & $<5$ hours \\
\hline Self-adhesive bandage & $<5$ hours \\
\hline$\cdot$ technique A - tactile pressure & 1 to 2 hours \\
\hline$\cdot$ technique - suture & 1 to 2 hours \\
\hline Microporous tape & \\
\hline$\cdot C(3 M)$ & 48 hours \\
\hline$\cdot D(C r e m e r)$ & 24 hours \\
\hline Transparent polyurethane film & 96 hours \\
\hline$\cdot E($ Systagenix $)$ & $\leq 24$ hours \\
\hline$\cdot F($ Smith \& Nephew) & \\
\hline$\cdot G(3 M)$ & \\
\hline$\cdot H(C u r a t e c)$ & \\
\hline
\end{tabular}

The application of the crepe bandage, the self-adhesive bandage and the microporous tape was illustrated in Fig. 1.
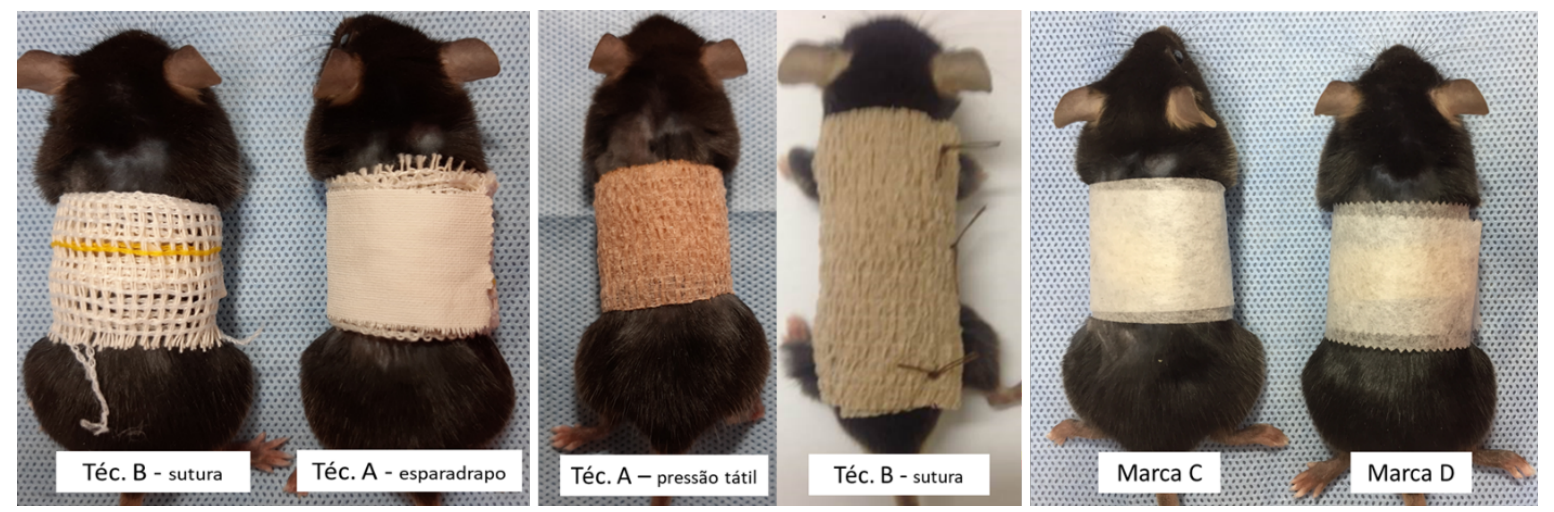

Figure 1. Fixation techniques employed with crepe bandage, self-adhesive bandage and microporous tape. Belo Horizonte (MG) - 2019.

The crepe bandage was wrapped around the animal's body and the tip fixed with adhesive tape to simulate the reality of clinical practice (technique A) and with suture stitches (technique B). In both forms, the dressing time on the wound did not exceed 1 hour and 30 minutes. 
The self-adhesive bandage was applied in two different ways, one by means of tactile pressure (technique A). However, it was not possible to apply adequate pressure to adhere to the bandage due to the mouse's body structure, which does not resist the tactile pressure necessary for self-adherence of this bandage. In the other way, the bandage was applied around the animal's body and sutured with a cotton thread in the proximal and distal portions (technique B). However, it was observed that the animal was able to sneak out of the tubular structure formed by the bandage. In the five attempts made in this modality, the dressing time in the wound bed did not reach five hours.

When fixing the dressing with microporous tape marks $\mathrm{C}\left(3 \mathrm{M}^{\circledR}\right)$ and $\mathrm{D}\left(\mathrm{Cremer}^{\circledR}\right)$, the residence time was, at most, two hours for the two marks evaluated. The animals were able to chew the tape on the lateral regions and, with that, expose the primary cover and the wounds.

The use of the polyurethane film as a secondary covering was illustrated in Fig. 2 and the sequence of application of it was demonstrated in Fig. 3, as primary covering (a to d) and secondary covering (a' to d'), respectively.
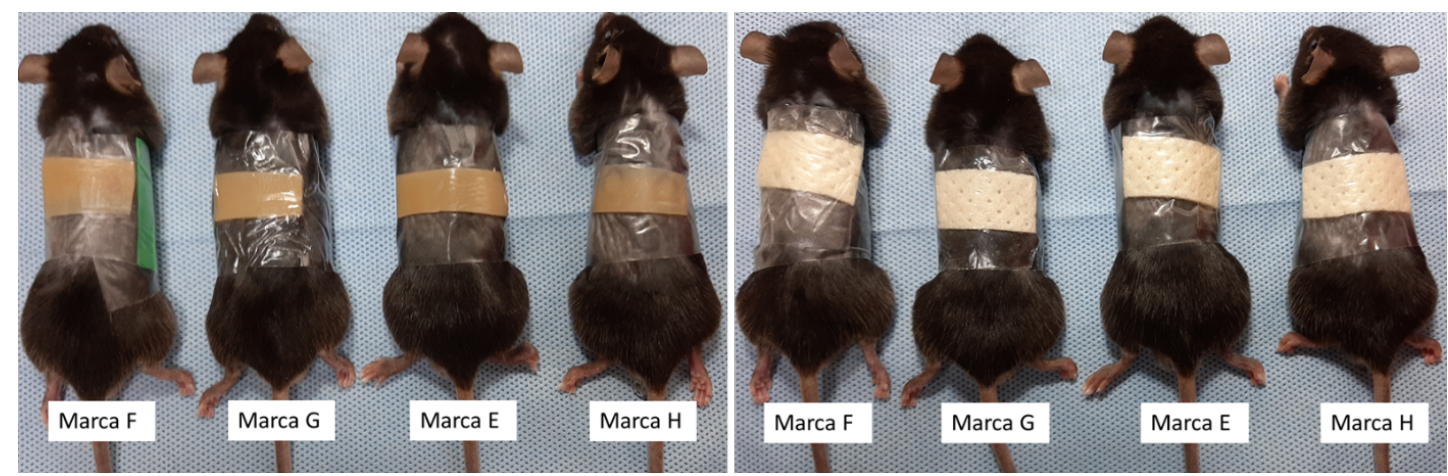

Figure 2. TFixation techniques using transparent polyurethane film as a secondary dressing. Belo Horizonte (MG) - 2019.
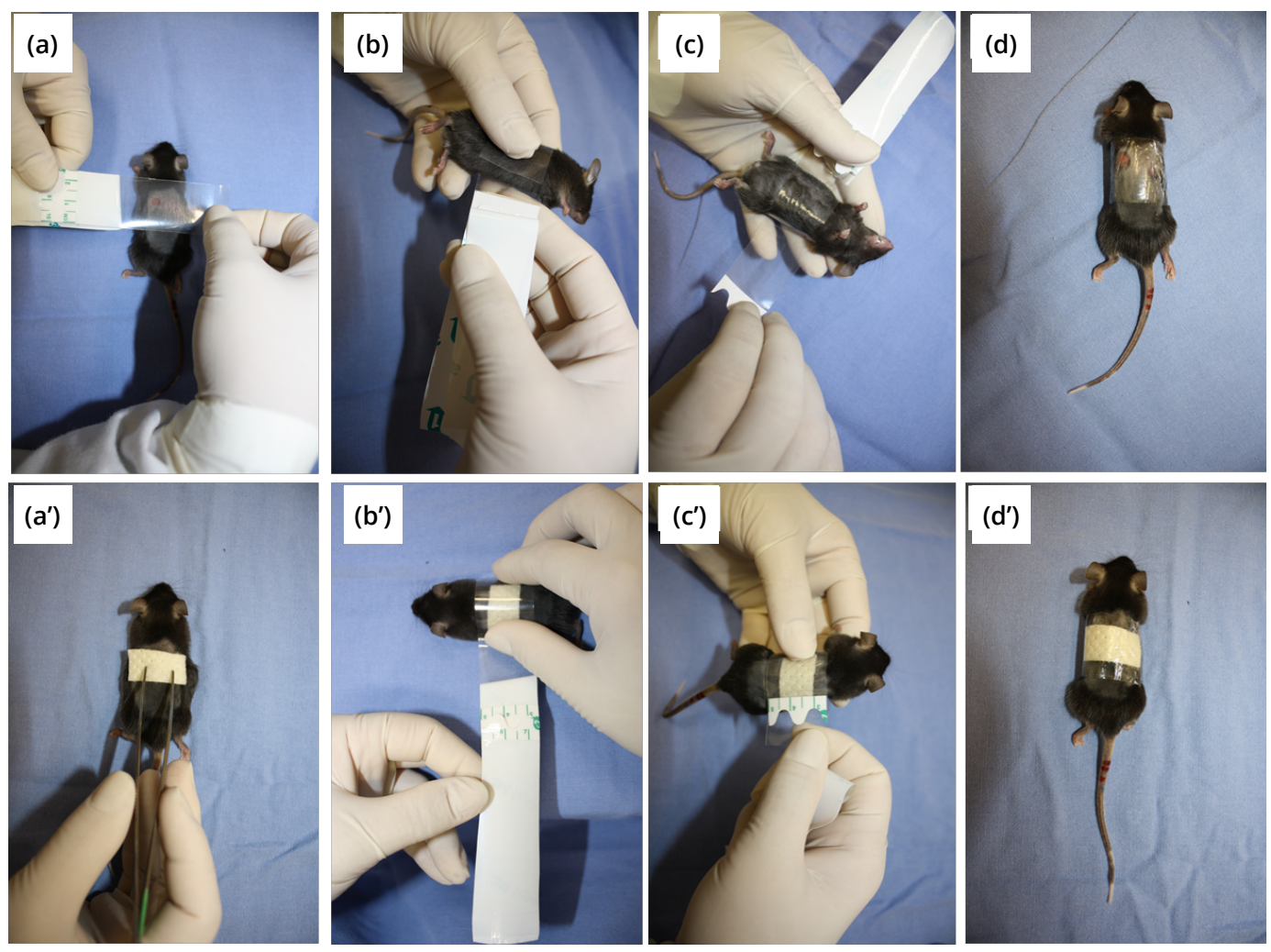

Figure3. Sequence ofapplication ofthetransparentfilmasa primarydressing(atod)and asa secondarydressing. Belo Horizonte (MG) - 2019. 
The four brands of polyurethane film, called E (Systagenix $\left.{ }^{\circledR}\right), F\left(\right.$ Smith \& Nephew $\left.{ }^{\circledR}\right), G\left(3 M^{\circledR}\right)$ and H $\left(\right.$ Curatec $^{\circledR}$ ) were applied with a complete loop around the animal's body. This type of fixation allowed the animals to gnaw on the film until it broke, with exposure of the covering and the wound. The dressing time was up to 36 hours for the $\mathrm{E}$ and $\mathrm{G}$ brands, and less than 24 hours for the $\mathrm{F}$ and $\mathrm{H}$ brands.

The same marks of polyurethane film were applied giving two complete turns around the animal's body. The dressing time was longer for the $\mathrm{E}\left(\right.$ Systagenix ${ }^{\circledR}$ ) and $\mathrm{G}\left(3 \mathrm{M}^{\circledR}\right)$ marks, with 48 and 96 hours, respectively. The brands $\mathrm{F}$ (Smith \& Nephew ${ }^{\circledR}$ ) and $\mathrm{H}\left(\right.$ Curatec $\left.^{\circledR}\right)$ had a time of 24 hours and less than 24 hours, respectively.

The evaluation of the coverage for application on the wounds confirmed that the rectangular shape in the dimension of $1 \mathrm{~cm}$ long by $2 \mathrm{~cm}$ wide (vertical $\mathrm{x}$ horizontal) showed better performance for maintaining the dressing on the wound bed. In this experiment, no adverse events were observed on the skin around the wounds. The applied dressings were maintained and observed until the animal itself removed them or there was loss of adhesion (natural detachment) of the dressing. This positioning considered that the objective of this study was to evaluate the duration of the dressing on the wounds, so there were no interventions, such as removal or punctual change of the dressing.

The results made it possible to establish recommendations for the adoption of the dressing fixation model (Table 2).

Table 2. Standardizations for making an excisional wound, applying and fixing dressings. Belo Horizonte (MG) - 2020.

\begin{tabular}{|c|c|}
\hline Standardized variable & Results \\
\hline Place for making the excisional wound & Middle dorsal region* \\
\hline Wound size (surgical punch) & $5 \mathrm{~mm}^{*}$ \\
\hline Distance between wounds & 0.5 to $1.0 \mathrm{~cm}$ in the vertical and horizontal direction ${ }^{* *}$ \\
\hline Number of wounds to be made & 2 or more according to the proposed study ${ }^{* *}$ \\
\hline Shape and size of the occlusive dressing & Rectangular $1 \mathrm{~cm}$ long $\times 2 \mathrm{~cm}$ wide (vertical $\times$ horizontal) \\
\hline Standardized product for dressing fixation & G brand polyurethane film (3M) \\
\hline Polyurethane film format (fixation) & Rectangular** \\
\hline Polyurethane film size (fixation) & $3 \mathrm{~cm}$ long x $15 \mathrm{~cm}$ wide (vertical $\times$ horizontal) ${ }^{* *}$ \\
\hline
\end{tabular}

*Adapted from Canesso et al, 2014; ** Research data

\section{DISCUSSION}

The treatment of skin wounds, despite the continuous progress in the generation of clinical evidence, is still a challenge for health professionals, being of fundamental importance the development of pre-clinical research in order to find new technologies and, mainly, to highlight the effective products that comply with the proposal presented by the industry.

The differences between species of mice (Mus musculus) in the repair of murine and human skin, such as contraction promoted by the fleshy panicle (muscle layer) and the role of specific niches of skin stem cells, do not preclude the performance of preclinical studies. The murine model, despite the innumerable morphofunctional, immunological and genetic differences, has contributed a lot to the understanding of normal and pathological skin repair in humans. The healing of the skin wound is similar in humans and mice when considering the distinct and overlapping phases of highly complex cellular and molecular events: homeostasis, inflammation, proliferation and remodeling ${ }^{11}$.

The mouse was chosen for this study because it is the most commonly used animal model, especially in studies of physiology and biochemistry, as they are easy to handle and maintain, in addition to being economically accessible. They can be standardized by age, sex, history and genetic predisposition, and allow the use of a relatively high number of animals for statistical validationHow to cite. However, the mouse has a small body, which makes it difficult to fix and maintain the dressings when assessing wound treatment. 
The middle dorsal region was defined as the best place for making excision wounds in mice of the C57BL/6 strain due to the physical constitution of these animals, corresponding to the largest area for the application and adhesion of dressings. It was also delimited that two wounds would be made on the backs of these animals so that the application and fixation of the dressing would occur more closely to the biophysics involved in the treatment of wounds. In addition, it was defined that the minimum distance between the wounds would be 0.5 to $1.0 \mathrm{~cm}$ in both directions (vertical and horizontal), especially when it comes to studies that involve making a number of excisional wounds $\geq$ to $2^{9}$.

The evaluations demonstrated that the application of a single block covering $(1 \mathrm{~cm} \times 2 \mathrm{~cm}$ rectangle) was the most appropriate technique, as it allowed the occlusion of the wound area and ensured a small margin of exposed skin around the wound, reducing the time required for application. of the cover and fixation of the dressing, facilitating the handling of the cover and, consequently, reducing handling and stress of the animal.

The model of excision cutaneous wounds used as a reference, which establishes the making of four wounds on the dorsum of the mouse ${ }^{9}$, is reproducible, in addition to being widely accepted for the study of skin wounds. Likewise, the amount of wounds to be made is directly proportional to the amount of material needed for histological and/or immunohistochemical analyzes proposed.

Thus, the adaptation of this model to two wounds contributes to the maintenance of the animals' well-being during the experiment, as its spoliation is reduced by $50 \%$ and the possibility of discomfort and pain is less than in the model of four skin wounds.

At the end of this study, it was defined that the best fixation of the dressing is that made with transparent non-sterile polyurethane film of the $\mathrm{G}\left(3 \mathrm{M}^{\circledR}\right)$ brand, measuring $3 \mathrm{~cm}$ in length by $15 \mathrm{~cm}$ in width, applied over the primary covering or over the different types of wound care products.

The dimensions of the polyurethane film that allowed the application in two complete rounds around the mouse body ensured a longer dressing time (96 hours) when compared to just one round, which allowed a time of up to 48 hours. In addition, the length ensures that the polyurethane film is applied to the animal in order to overlap the primary cover used, ensuring a safety margin for the product's adherence to the animal's skin.

There are a large number of studies developed in experimental models ${ }^{12,13}$. However, these models used to evaluate wound treatment do not fully contemplate the principles of ideal dressing. Many are not able to provide an adequate environment for healing and materialize the reality of clinical practice.

The products used in the study for fixing dressings are routinely adopted by professionals in clinical practice. The choice of these products was directly related to the location of the wound and the characteristics of the product used to treat it.

Some experimental studies in murine models do not mention or describe the methods used clearly for the application and fixation of the dressing ${ }^{14,15}$. The main challenges for replicating these studies are gaps in information and variations in the way of applying the products investigated by the researchers.

Among the published experimental studies, some have described ways of fixing dressings in animal models ${ }^{10,16,17}$ that served as support and guidance for the standardization of the dressing model used in this study in question.

A study ${ }^{16}$ describes the use of a biopolymer membrane fixed with a conventional dressing (sterile gauze and tape) in the treatment of excisional cutaneous wounds in rats, the exchange being performed every 2 or 3 days, during the experimental times of 7, 14, 21 and 40 days after making the wounds. However, this fixation model did not work in the evaluations carried out in this study.

A research involving skin wounds of a total thickness of $6 \mathrm{~mm}$, made on the dorsum of the mice, was treated with nanoparticles of $\alpha$-gal (AGN). The product was applied topically on days 0 and 1 after the wound. Then, the wounds were occluded with Tegaderm ${ }^{\mathrm{TM}}\left(3 \mathrm{M}^{\circledR}\right)$ transparent film and the animals involved circumferentially with a self-adhesive Coban $^{\mathrm{TM}}\left(3 \mathrm{M}^{\circledR}\right)$ bandage. The aggregation of the cover and bandage showed the ability to maintain the nanoparticles on the wound ${ }^{17}$.

In another study ${ }^{18}$ the silicone dressing was sutured with nylon threads to evaluate the healing of excisional skin wounds in animals with induced chronic kidney disease. Immediately after applying this plate, polyurethane film (3M) was applied as secondary dressing. The tissue from the wounds was collected at 3,7 and 14 days after its preparation, when the fixation 
was removed. This polyurethane film was the same as in the study that managed to keep the dressing in place for 96 hours, when used with two turns on the mouse's body.

Another study also used the suture to maintain dressing over the wound ${ }^{10}$. There is a description of the fixation of a gel composed of platelet-rich plasma in the topical treatment of surgically induced second and third degree burns. The gel was applied over the lesion and fixed by means of a semi-rigid plastic disc attached around the wound with surgical stitches. Then, the researcher wrapped the animals' chest with adhesive tape to avoid removing the dressing by them. The suture of the disc was maintained for 5 days and after that period no dressing was applied to the wounds.

As in the aforementioned studies, in this research, the proposal for secondary coverage through the use of polyurethane film was adopted. However, the suture was excluded to keep the dressing on the wound, as this practice can interfere with the healing process as it is a source of trauma during its performance. In addition, each dressing change requires making a new suture.

Fixation with polyurethane film was tested, evaluated and adjusted for two turns on the animal's back, making it possible to standardize the fixation of dressings in the studies carried out by the researchers to evaluate the treatment of wounds in an animal model (mouse).

For making the wounds, the criteria regarding the location and size of the wound were maintained. It was considered that the $5 \mathrm{~mm}$ surgical punch is sufficient to make the wound and remove the tissue. Regarding the location, it was found that the more centralized the wound disposition (middle dorsal region), the greater the possibility of adhesion and fixation of the dressing. Such facts facilitate the application of the covering and the fixation of the dressing on the mouse.

The polyurethane film can be used as a primary covering to promote occlusion of the lesion or as a secondary covering, that is, to fix the applied dressing. The results achieved during the dressing fixation standardization experiment are similar to the procedures performed by professionals in clinical practice for fixing dressings on the wounds subjected to treatment. Chronic wounds are more similar because they require frequent dressing changes over a long period of time. This characteristic requires greater care from professionals to implement care aimed at maintaining the integrity of the skin around the wound, where the dressings are adhered.

Despite the progress in translational research on skin wound healing in the past few decades, no animal model fully predicts all clinical outcomes ${ }^{11}$. However, the standard for dressing fixation is essential to ensure that the chosen treatment remains on the wound on the mouse's back for the prescribed time, in addition to preserving the integrity of the skin around the wound.

The experimental model partly materializes the process of dressing changes in the treatment of wounds carried out by nurses in order to assist in the development of new research in the area. It was possible to establish a dressing fixation model in mice with a 96-hour durability with the use of the $\mathrm{G}\left(3 \mathrm{M}^{\circledR}\right)$ polyurethane film, cut to size $3 \mathrm{~cm}$ long by $15 \mathrm{~cm}$ wide, giving two turns in the animal's body. The dressing permanence time meets the demands of the animal experiment segments. Thus, this model will contribute to nurses in fixing dressings in their practice and also during research involving coverage analysis, wound treatment and tissue repair.

\section{CONCLUSION}

The study presents an advance in knowledge, since it establishes a dressing fixation model for wounds in mice with a product available in Brazil and compatible with the animal's body structure. In addition, the $G\left(3 \mathrm{M}^{\circledR}\right)$ polyurethane film and the technique of wrapping the mouse's body with two turns were resistant to the movements and action of the animal's teeth.

It is recommended that the proposed fixation model be used by nurses. It must also be expanded to other animals to confirm the effectiveness of the product (polyurethane film) and technique (two turns) with necessary adjustments to the dimension of the film (width $\mathrm{x}$ length), according to the size of the wound and its location. 


\section{AUTHORS' CONTRIBUTION}

Conceptualization: Borges EL e Amorim GL; Methodology: Borges EL; Research: Amorim GL, Guillen MRS and Vieira PC; Writing - First version: Amorim GL and Guillen MRS; Writing - Review \& Editing: Borges EL; Financing Acquisition: Borges EL and Amorim GL; Resources: Amorim GL, Guillen MRS and Vieira PC; Supervision: Borges EL.

\section{DATA STATEMENT AVAILABILITY}

All data were generated or analyzed in the present study

\section{FUNDING}

Fundação de Amparo à Pesquisa do Estado de Minas Gerais

https://doi.org/10.13039/501100004901

Grant No: CDS-APQ-00904-15

\section{ACKNOWLEDGMENTS}

To Department of Physiology and Biophysics of the Universidade Federal de Minas Gerais - Instituto de Ciências Biológicas for logistical support in the use of spaces and equipment.

\section{REFERENCES}

1. Storey S, Wagnes L, LaMothe J, Pittman J, Cohee A, Newhouse R. Building evidence-based nursing practice capacity in a large statewide health system: A Multimodal Approach. J Nurs Adm. 2019;49(4):208-14. https://doi.org/10.1097/ NNA.0000000000000739

2. Perry CJ, Lawrence AJ. Hurdles in basic science translation. Front Pharmacol. 2017;8:478. https://doi.org/10.3389/ fphar.2017.00478

3. Rowsey PJ. Using animals in nursing research: bridging gaps between bench, bedside, and practice. West J Nurs Res. 2015;37(12): 1515-6. https://doi.org/10.1177/0193945915578815

4. Lodhi S, Vadnere GP. Relevance and perspectives of experimental wound models in wound healing research. Asian J Pharm Clin Res. 2017;10(7):57-62. https://doi.org/10.22159/ajpcr.2017.v10i7.18276

5. Cai H, Li G. Efficacy of alginate-and chitosan-based scaffolds on the healing of diabetic skin wounds in animal experimental models and cell studies: a systematic review. Wound Rep Reg. 2020; 28(6):751-71. https://doi.org/10.1111/wrr.12857

6. Parnell LKS, Volk SW. The Evolution of Animal Models in Wound Healing Research: 1993-2017Adv in wound care (New Rochelle). 2019;8(12):692-702. https://doi.org/10.1089/wound.2019.1098

7. $\mathrm{Hu}$ J, Guo S, Hu H, Sun J. Systematic review of the efficacy of topical haemoglobin therapy for wound healing. Int Wound J. 2020;17:1323-30. https://doi.org/10.1111/iwj.13392

8. Cashion A, Pickler RH. What Will I Bring: Nurse Scientists' Contributions to Interdisciplinary Collaboration. Nurs Res. 2018;67(5):347-48. https://doi.org/10.1097/NNR.0000000000000299

9. Canesso MCC, Vieira AT, Castro TBR, Schirmer BGA, Cisalpino D, Martins FS et al. Skin wound healing is accelerated and scarless in the absence of commensal microbiota. J Immunol. 2014;193(10):5171-80. https://doi.org/10.4049/jimmunol.1400625

10. Masson-Meyers DS, Andrade TAM, Caetano GF, Guimaraes FR, Leite MN, Leite SN et al. Experimental models and methods for cutaneous wound healing assessment. Int J Exp Pathol. 2020;101(1-2):21-37. https://doi.org/10.1111/iep.12346

11. Zomer HD, Trentin AG. Skin wound healing in humans and mice: challenges in translational research. J Dermatol Sci. 2018; 90(1):3-12. https://doi.org/10.1016/j.jdermsci.2017.12.009

12. Cetinkaya RA, Yilmaz S, Ünlü A, Petrone P, Marini C, Karabulut E et al. The efficacy of platelet-rich plasma gel in MRSA-related surgical wound infection treatment: an experimental study in an animal model. Eur J Trauma Emerg Surg. 2018;44(6):859-67. https://doi.org/10.1007/s00068-017-0852-0 
13. Nikpasand A, Parvizi MR. Evaluation of the effect of titatnium dioxide nanoparticles/gelatin composite on infected skin wound healing; an animal model study. Bull Emerg Trauma. 2019;7(4):366-72. https://doi.org/10.29252/beat-070405

14. Park SA, Covert J, Teixeira L, Motta MJ, DeRemer SL, Abbott NL et al. Importance of defining experimental conditions in a mouse excisional wound model. Wound Repair Regen. 2015;23(2):251-61. https://doi.org/10.1111/wrr.12272

15. Stoffel JJ, Riedi PLK, Romdhane BH. A multimodel regime for evaluating effectiveness of antimicrobial wound care products in microbial biofilms. Wound Repair Regen. 2020;28(4):438-47. https://doi.org/10.1111/wrr.12806

16. Lucena MT, Melo Júnior MR, Lira MMM, Castro CMMB, Cavalcanti LA, Menezes MA et al. Biocompatibility and cutaneous reactivity of cellulosic polysaccharide film in induced skin wounds in rats. J Mater Sci Mater Med. 2015;26(2):82. https://doi. org/10.1007/s10856-015-5410-x

17. Kaymakcalan OE, Abadeer A, Goldufsky JW, Galili U, Karinja SJ, Dong X. et al. Topical a-Gal nanoparticles accelerate diabetic wound healing. Exp Dermatol. 2020;29(4):404-13. https://doi.org/10.1111/exd.14084

18. Seth AK, De la Garza M, Fang RC, Hong SJ, Galiano RD. Excisional wound healing is delayed in a murine model of chronic kidney disease. Plos One. 2013;8(3):e59979. https://doi.org/10.1371/journal.pone.0059979 